\title{
"Communication as an instrument for enhancing trust in a central bank: the case
}

of Ukraine"

\begin{tabular}{|c|c|}
\hline \multirow{5}{*}{ AUTHORS } & Yuliia Shapoval (D https://orcid.org/0000-0001-9965-5522 \\
\hline & R http://www.researcherid.com/rid/S-5145-2017 \\
\hline & Kateryna Anufriieva (D https://orcid.org/0000-0002-3179-8655 \\
\hline & Svitlana Brus (D) https://orcid.org/0000-0001-5373-273X \\
\hline & Yevhen Bublyk (D https://orcid.org/0000-0002-6080-9341 \\
\hline ARTICLE INFO & $\begin{array}{l}\text { Yuliia Shapoval, Kateryna Anufriieva, Svitlana Brus and Yevhen Bublyk (2019). } \\
\text { Communication as an instrument for enhancing trust in a central bank: the case } \\
\text { of Ukraine. Banks and Bank Systems, 14(2), 106-119. } \\
\text { doi:10.21511/bbs.14(2).2019.09 }\end{array}$ \\
\hline DOI & http://dx.doi.org/10.21511/bbs.14(2).2019.09 \\
\hline RELEASED ON & Friday, 07 June 2019 \\
\hline RECEIVED ON & Tuesday, 26 March 2019 \\
\hline \multirow[t]{2}{*}{ ACCEPTED ON } & Tuesday, 07 May 2019 \\
\hline & $((c)$ EY \\
\hline LICENSE & $\begin{array}{l}\text { This work is licensed under a Creative Commons Attribution } 4.0 \text { International } \\
\text { License }\end{array}$ \\
\hline JOURNAL & "Banks and Bank Systems" \\
\hline ISSN PRINT & $1816-7403$ \\
\hline ISSN ONLINE & $1991-7074$ \\
\hline PUBLISHER & LLC "Consulting Publishing Company "Business Perspectives" \\
\hline FOUNDER & LLC "Consulting Publishing Company "Business Perspectives" \\
\hline
\end{tabular}

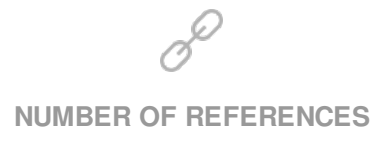

31

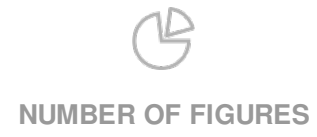

12

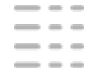

NUMBER OF TABLES

0

(C) The author(s) 2022. This publication is an open access article. 


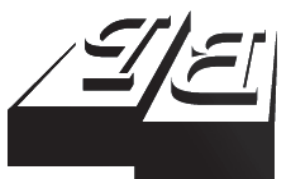

BUSINESS PERSPECTIVES

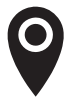

LLC "CPC "Business Perspectives” Hryhorii Skovoroda lane, 10, Sumy, 40022, Ukraine

www.businessperspectives.org

Received on: $26^{\text {th }}$ of March, 2019 Accepted on: $7^{\text {th }}$ of May, 2019

(C) Yuliia Shapoval, Kateryna Anufriieva, Svitlana Brus, Yevhen Bublyk, 2019

Yuliia Shapoval, Junior Research Fellow, Department for Monetary Relations, Institute for Economics and Forecasting, National Academy of Sciences of Ukraine, Ukraine.

Kateryna Anufriieva, Ph.D. in Economics, Senior Research Fellow, Department for Monetary Relations, Institute for Economics and Forecasting, National Academy of Sciences of Ukraine, Ukraine.

Svitlana Brus, Ph.D. in Economics, Senior Research Fellow, Department for Monetary Relations, Institute for Economics and Forecasting, National Academy of Sciences of Ukraine, Ukraine.

Yevhen Bublyk, Ph.D. in Economics, Senior Research Fellow, Department for Monetary Relations, Institute for Economics and Forecasting, National Academy of Sciences of Ukraine, Ukraine.

\section{(ㄷ) (i)}

This is an Open Access article, distributed under the terms of the Creative Commons Attribution 4.0 International license, which permits unrestricted re-use, distribution, and reproduction in any medium, provided the original work is properly cited.
Yuliia Shapoval (Ukraine), Kateryna Anufriieva (Ukraine), Svitlana Brus (Ukraine), Yevhen Bublyk (Ukraine)

\section{COMMUNICATION AS} AN INSTRUMENT FOR ENHANCING TRUST IN A CENTRAL BANK: THE CASE OF UKRAINE

\begin{abstract}
The relevance of trust in the central bank is determined by the rapid growth of the gap between the expectations of a regulator and market participants regardless of the reforms carried out by the NBU. Therefore, the need to use the "non-traditional" monetary policy instruments has enhanced the role of verbal interventions in the context of inflation targeting.

The aim of the article is to ground that trust causes adequate rational behavior of the market participants in response to the central bank's communication policy. The type of this research is an explanatory research method.

As determined, trust is the necessary condition for the effectiveness of the central bank's communication strategy and it favors the achievement of proclaimed objectives. It is established that although since 2014 the NBU activated verbal interventions as an additional instrument to anchor expectations, the increase of transparency does not prompt the trust because of the lack of confidence of citizens in the NBU and high level of stress in the domestic financial sector. It is emphasized that the pursuit of inflation targeting requires expanded communication to gather the expectations of economic agents. The NBU, in its communication policy concerning the economic climate, underlines devaluation expectations, the exchange rate and explanations on the discount rate. However, the deviation of expected enterprises' exchange rate from the actual exchange rate, growing velocity of money circulation against the declining share of funds involved in the banking system, low monetization level and low penetration of financial services evidence the distrust in monetary policy.
\end{abstract}

\section{Keywords}

\section{JEL Classification} monetary policy, verbal intervention, expectation, inflation, exchange rate, discount rate

E52, E58, E7

\section{INTRODUCTION}

During the latest four years, the National Bank of Ukraine (NBU) has been implementing reforms according to the Comprehensive Program of Ukraine Financial Sector Development until 2020. One of the major achievements of the reforms are the setting of inflation targeting, the mopping up of the banking sector (90 banks were liquidated), the limitation of lending to related parties, the establishment of the National Bank Credit Register, the transition to international standards for banks based on Basel III, the introduction of risk-oriented banking supervision (SREP), the raising of the standards of disclosure by banks, etc.

Despite that, spikes in inflation and depreciation have constantly eroded trust in the NBU's policy. In order to achieve a positive effect from the reforms, the NBU needs to prove its ability to achieve the stated goals. In this context, communication policy is an effective tool 
of monetary policy. As at the beginning of 2016, the NBU switched to the use of the inflation targeting regime, the central bank of Ukraine needs to communicate in an appropriate manner, that it targets a certain inflation rate (projected inflation is at $5 \% \pm 1$ in 2019).

\section{LITERATURE REVIEW}

It is universally acknowledged, that "communication can be a complement or a substitute for monetary policy. In those periods in which communication is more efficient in managing expectations, central banks may have less need for reliance on the traditional policy rate" (Ernst \& Merola, 2018).

From there, proceeding from the reaction of the U.S. Treasury bond market to innovations in macroeconomic fundamentals, Altavilla et al. (2014) state that "macroeconomic news explains about one-third of the low frequency (quarterly) fluctuations in long-term bond yields, whereas non-fundamental factors have substantial effects on the day-to-day movements of bond yields".

Meanwhile, "announcements of asset purchase programs have lowered market uncertainty, particularly when accompanied by a contextual release of implementation details such as the envisaged size of the program" (Coenen et al., 2017). The experts pointed out that "forward guidance reduces uncertainty more effectively when it is state-contingent" or "when it provides guidance about a long horizon than when it is open-ended or covers only a short horizon", and that the "credibility of forward guidance is strengthened if the central bank has also embarked on an asset purchase program".

Moreover, it is grounded that higher trust in the European Central Bank (ECB) "lowers inflation expectations on average, and significantly reduces uncertainty about future inflation" (Christelis et al., 2016). The scientists show that "the effect of trust is not uniform across the distribution of inflation expectations: at the lower end of the distribution, an increase in trust upsurges inflation expectations, while the opposite is true at the higher end of the distribution of inflation expectations".

In view of that, Blinder et al. (2017) revealed that "central banks in crisis countries are [...] more likely to have resorted to new policies, to have had discussions about mandates, and to have communicated more. [...] But the thinking has changed more broadly - for instance, central banks in non-crisis countries" also report having "implemented macro-prudential measures". That way, "non-monetary news accounts for a significant part of financial markets' reaction during the financial crisis and in the early recovery, while monetary shocks gain importance since 2013" (Cieslak \& Schrimpf, 2018).

In addition, Lustenbergera and Rossib (2017) draw attention to the "limited country- and variable-specific effects of central bank transparency on forecast accuracy and their dispersion among a large set of professional forecasts of financial and macroeconomic variables". According to them, more communication even increases forecast errors and dispersion.

Blinder (2018) predicts that transparency of monetary policy will advance over time. "Although central banks will keep trying to communicate with the general public, for the most part, they will fail. So, the issue of improving monetary authority's communication at a time, when trust in public institutions has fallen and while the responsibilities delegated to central banks have increased, is on the agenda today" (Bholat et al., 2018). In this respect, the researchers suggest that a "Visual Summary of the inflation report improves comprehension of its main messages in a statistically significant way compared to the traditional executive summary".

Communication regarding the future normalization of monetary policy will be a significant challenge for the ECB. "The normalization of monetary policy encompasses terminating QE (which has already started), increasing interest rates above the ELB observed prior to the GFC and downscaling" the ECB's "balance sheet to the pre-crisis level". The experiences of the Federal Reserve System (Fed) "highlight the importance of precise communication. Ineffective or imprecise communication can result in escalation of financial market volatility. The American experience suggests that 
central banks should be very explicit about the state dependency of monetary policy normalization" (Janikowski \& Rzonca, 2018, p. 26).

Generally, the transition to the practice of inflation targeting in the early 1990s led to an increase in openness in disclosing goals and mandates, for example, publication of future policy rates. This action has provided central banks with more leverage to achieve the objectives of monetary policy. Central banks not only forecast the dynamics of the key interest rate and thus manage inflationary expectations, but also provide the public with comments on any deviations from targets in previous forecasts (Romanchukevych \& Lymanska, 2018, p. 70).

The implementation of inflation targeting strategy by Ukrainian central bank involves the public announcement of inflation targets and the bank's obligation to achieve these goals and therefore many communication tools (Savchenko \& Zakutniaia, 2017, p. 42).

Along with the purpose of the NBU's communication policy for the formation and management of the expectations of economic entities, the promotion of confidence in central bank actions is also vital. Disclosure of the measures that are being implemented is open to the general public, and its actions thus acquire higher transparency. This increases the level of accountability of the NBU and enhances trust in it (Mishchenko et al., 2015, p. 9). Timely informing external users of information is the key to public support for monetary policy conducted by the central bank (Svitlychna, 2014, p. 139).

At the same time, Ukrainian scientists point out that the disclosure of the key rate forecast will have a positive effect only if the inflation expectations are anchored and a high level of confidence in the actions of the NBU is ensured, while the publication of the monetary policy rules provided that the market participants understand it correctly (Shkolnyk, 2018, p. 114).

As a result of the literature review, a conclusion can be made about the interrelationship between the institute of trust and the effective communication of the central bank: transparency promotes confidence in the monetary policy.

\section{METHODS}

While writing this article, methods of scientific abstraction and generalizations were used - to disclose the theoretical model of the interconnection of trust and central bank policies' effectiveness; comparative analysis - to study the communication channels of central banks of developed countries and Ukraine; expert assessments - to determine the level of NBU transparency according to Dincer and Eichengreen methodology; quantitative analysis of the expressions in NBU's inflation report, Ukrainian currency market, dollarization, expectations of business; methods averaging of data and retrospective analysis of the monetary funds entrusted to the Ukrainian banking sector; concretization and analogy - to formulate recommendations on improving the communication policy of the central bank by keeping in mind the factors of trust and financial penetration.

\section{RESULTS}

Sufficient level of trust is a necessary condition for the effectiveness of the central bank's communication strategy. The trust causes adequate rational behavior of the market participants in response to the communication strategy of the central bank. Along with that, achieving proclaimed objectives for inflation, exchange rate, and business activity causes further increase in the level of trust. That is a positive self-reproduction process (Figure 1). The "long-forecasted" behavior and effect on expectations should materialize as the core of the central bank communication utilized as the monetary policy instrument. The need for such communication stems from the range of prerequisites, including the chosen inflation targeting and exchange rate regimes, and is stipulated by independence, transparency and term focus.

The current practice of monetary regulation by central banks of developed countries shows the growth of the role of an instrument such as communication policy. As Draghi, president of the ECB, pronounced: "Today, central bank communication is right at the heart of monetary policy. It is actually a monetary policy tool in itself [...] From the outset, we have taken a lead on transparency: for example, we were the first major cen- 


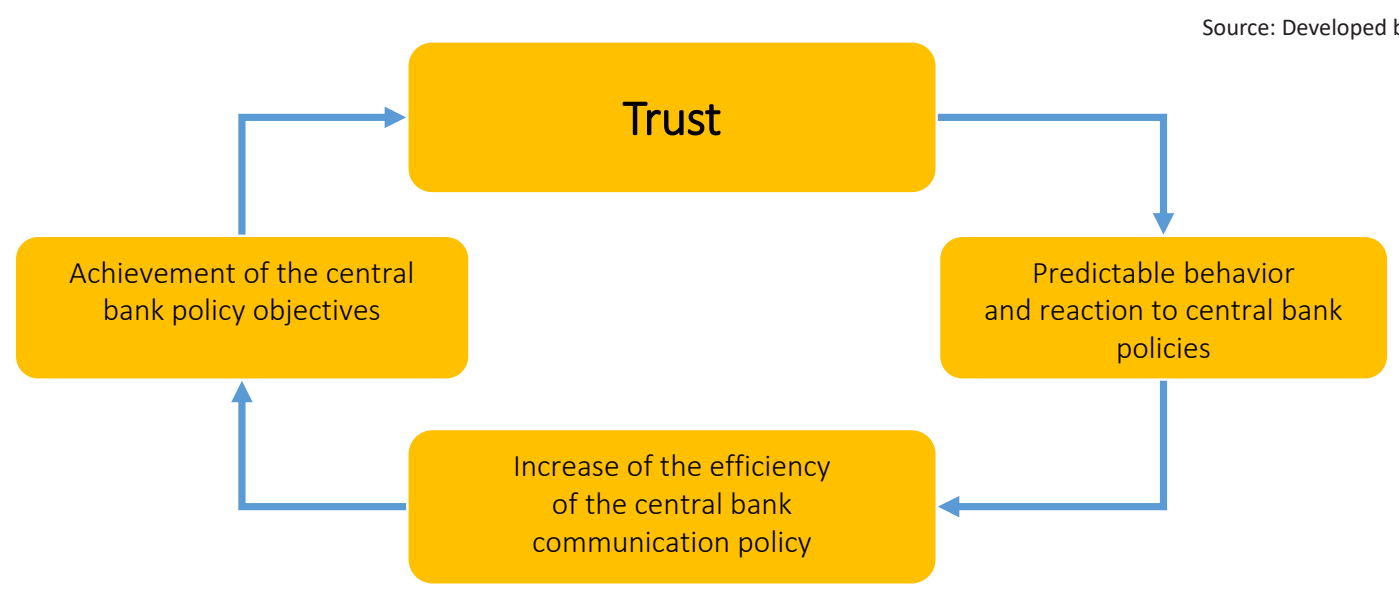

Figure 1. Interplay of trust and central bank policies' effectiveness

tral bank to offer monthly press conferences. But in these challenging times, when monetary policy has become more unconventional, we cannot stand still” (Draghi, 2014).

In the early 2000s, the communications between the ECB and the Bank of England (the BoE) had a little and short-term impact, and after the 2008 financial crisis, the intensity of the use of verbal interventions increased: in terms of fiscal policy and quantitative easing programs (Figure 2). One of the key examples of the powerful effect of the verbal intervention was the famous statement by Draghi: "Within our mandate, the ECB is ready to do whatever it takes to preserve the euro. And believe me, it will be enough" (Draghi, 2012). One phrase then turned out to be sufficient to weak- en the tension in financial markets. In four years, the ECB announced a number of additional measures of the QE. Although the reaction of financial markets to the declared measures was favorable, Draghi notified that "the ECB will no longer reduce interest rates". Despite the fact that the announced decisions of the Governing Council ensured a relaxation of monetary and financial conditions, Draghi's statement that the monetary policy of the ECB could only be tightened changed the expectations of agents regarding future policy.

In turns, verbal intervention by the Fed chairman Bernanke in May 2013 on Fed's willingness to curtail the quantitative easing program caused taper tantrum: the outflow of capital from the bond market. Overall, the Fed in its communication policy

Source: Compiled based on Cieslak and Schrimpf (2018).

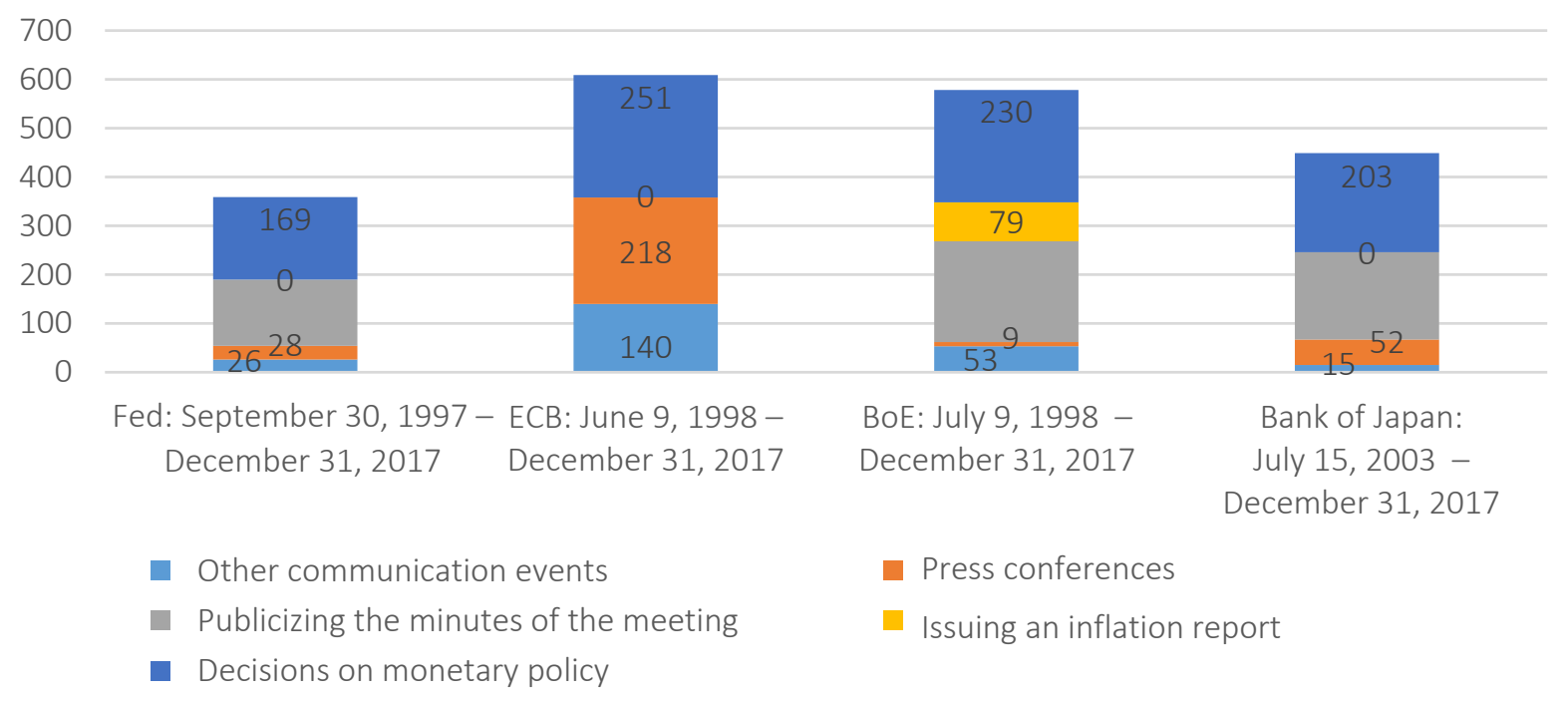

Figure 2. Communication channels of central banks of developed countries 
Source: Compiled based on Dincer and Eichengreen (2014).

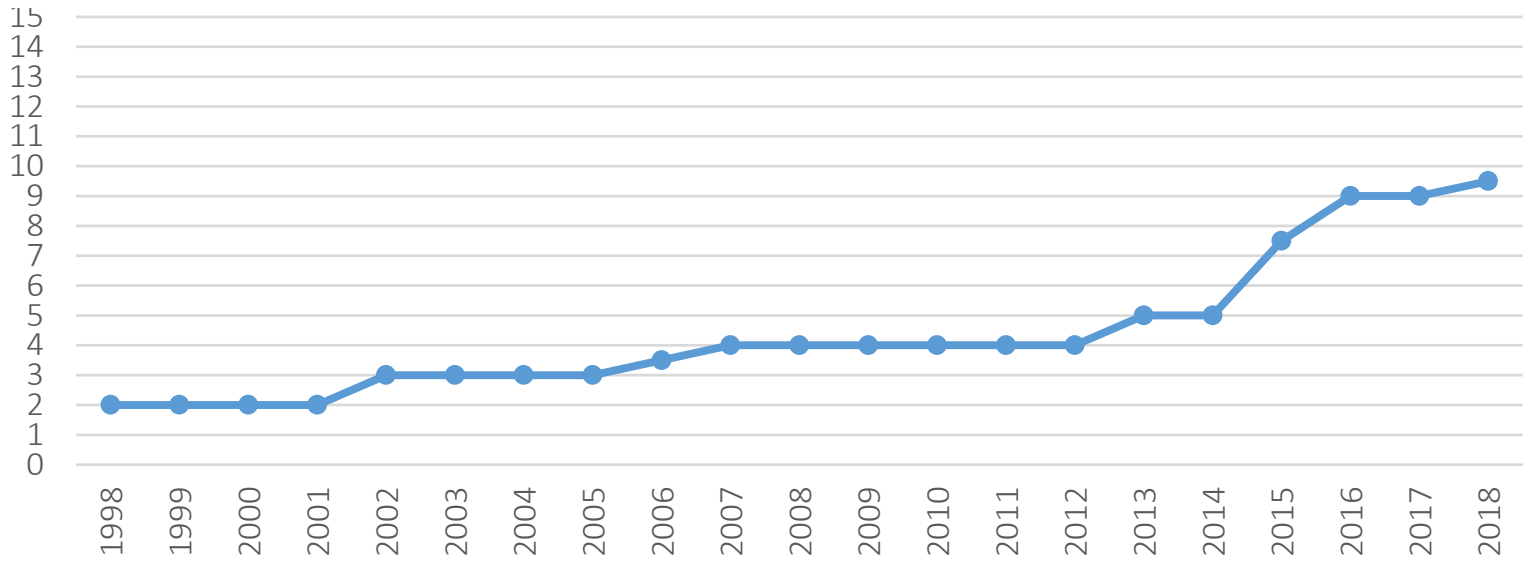

Figure 3. Central bank transparency index for Ukraine, 1998-2018

is changing the priorities between targeting inflation and stimulating economic activity in turn. In addition, verbal interventions of central banks of developed countries relate rarely to foreign economic activity and exchange rate fluctuations.

Whereas, NBU's new communication strategy indicates an awareness of this trend of modern monetary regulation. So, official public notices from our regulator began to come out more often. Further activation of the communication policy of the NBU, in particular, the run-up of the number of answers of mass media, press conferences and speeches forwarded the level of NBU's transparency (Figure 3). The rise in the number of communication channels and types of reporting pushed the NBU's transparency index to 9.5 by 2018 from 2 in 1998.

The NBU used verbal interventions as a massive additional instrument to anchor expectations in the aftermath of the political events in 2014 and the outbreak of the geopolitical conflict bursting large-scale instability in the financial sector. Such instability was caused by a number of reasons: decrease in loan servicing and correspondent unprecedented growth of non-performing loans, crunch of international credit to Ukraine with the impact of the international reserves' stock and the need for foreign debt reprofiling, the development of the sovereign-bank loop, which was dragging banks which had sovereign bonds as a part of asset portfolio. These had a tremendous effect both on the dynamics of the hryvnia exchange rate and, following the influence links, on inflation.
The regulator's information disclosure among others was encouraged by the cooperation with the IMF, resumed in 2014, on providing new funding. The NBU transparency policy has been recognized worldwide: in March 2019, the NBU received the prestigious international Central Banking Transparency Award for making progress in advancing communication (the award has been granted by the British publishing house Central Banking Publications within the Central Banking Awards 2019 ceremony in London). At the same time, it is important to mention that upgrading the transparency level being rather the quantitative measurement per se (implying periodicity of communication cases, variety of channels) does not prompt the level of trust and might influence the expectations of the economic agents, inter alia as regards inflation and exchange rate, opposite to the regulator's intention.

In fact, data from studies show that the practical significance of communication is still low. In particular, the reports that the NBU produces to influence the participants in the foreign exchange market are not systemic, situational, produced with a delay, and, most importantly, weakly correlate with the subsequent behavior of the market. A significant reason for this is a low level of confidence of market participants in the NBU activities. According to Razumkov Center (2019) social research data, $68.2 \%$ of citizens expressed their lack of confidence in the NBU in February 2019. Over the past two years, this indicator has remained practically the same. At such a low level of distrust, the effectiveness of modern monetary 


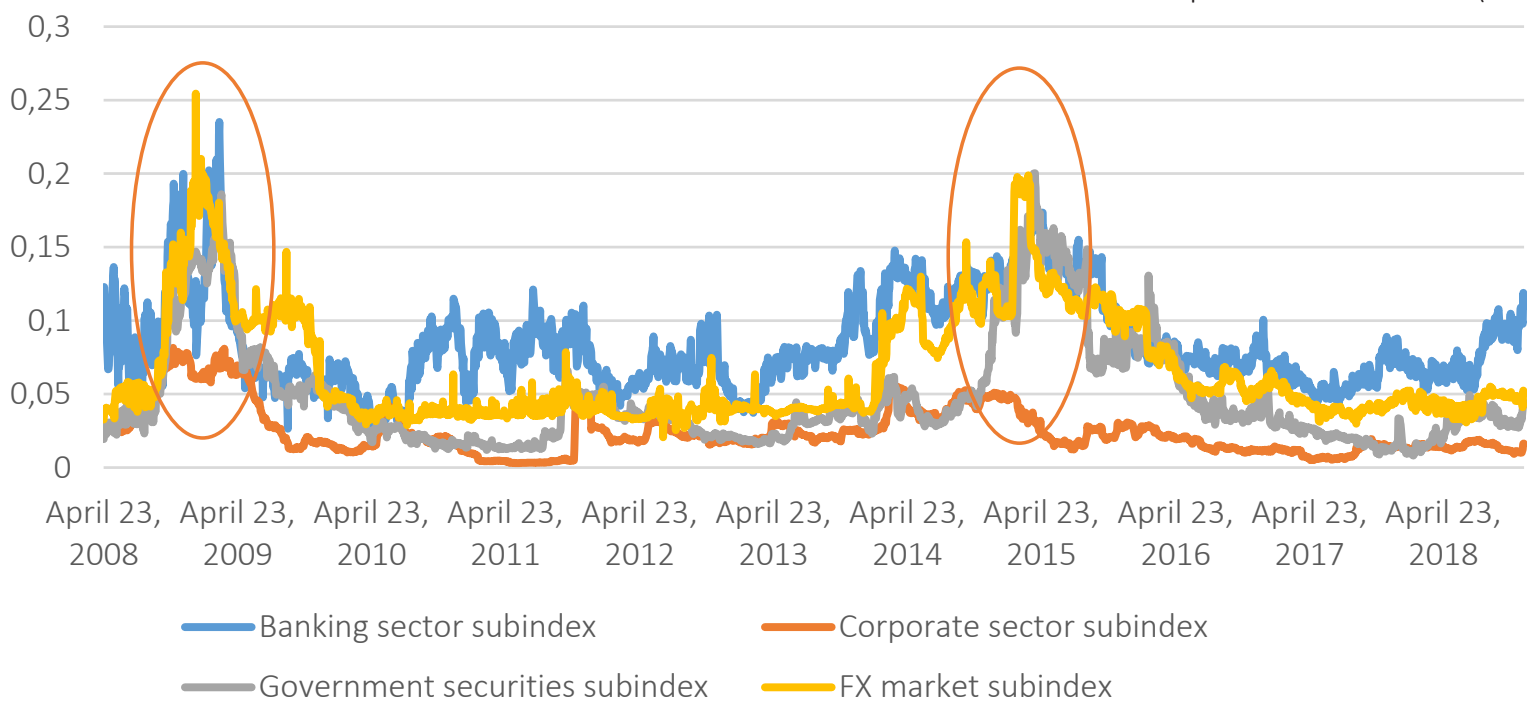

Figure 4. The Financial Stress Index for Ukraine, 2008-2018

policy instruments of the NBU cannot be effective in relation to a wide range of market participants. Small business and the population prefer to stay away from the banking market. Thus, the ratio of net bank assets to the country's GDP decreased from $73 \%$ in 2016 to $61 \%$ in 2018 .

Moreover, the Financial Stress Index reflects the distrust among market participants and signals that there is a high level of stress in the domestic financial sector (Figure 4). It is slightly growing, driven largely by the banking sector sub-index. The communication policy could have neutralized the peaks in the crisis of 2008-2009, 2014-2015 periods characterized by high uncertainty and a high rate of change in rates, spreads and prices. Furthermore, since the taking place of information asymmetry, the possible threats capable of threatening financial stability also exist in stable periods on Ukrainian financial market.

According to Ukrainian Main Guidelines for the Money-and-Credit Policy for 2016-2020 adopted by the NBU Regulation dated August 18,2015 , the NBU committed to regularly inform the society on the reached targets via the Inflation Report, press releases, conferences and other communication events. Among the tasks, the NBU identified re-focus of the social attention to inflation rather than exchange rate fluctuations. The Monetary policy strategy provided for by the Guidelines reserves inflation targeting regime aims at setting monetary policy goals for the mid-term perspective. As stated by the IMF, inflation targeting requires central bank independence and targeting of other indicators such as wages, the level of employment and exchange rate. The latter proves once again the interdependence of inflation and exchange rate (Jahan, 2018). The declared inflation targeting clearly stipulates for forward-looking planning and communication of the central bank to assess and influence expectations of economic agents. In the meantime, although the ECB, the Fed, the Bank of Japan, and the Swiss National Bank have adopted inflation targeting, they did not commit to announcing explicit numerical targets.

Specifically, the NBU uses the publication of the Inflation Report as a communication channel to create a predictable business environment for investment. However, these reports show a significant role of the exchange rate. In particular, the phrase "exchange rate" is found tens of times more often than the phrase "inflation targeting". This confirms that the NBU, in its communication policy with an emphasis on inflation, reflects a vision of the current and future state of the Ukrainian economy, taking into account an important factor such as devaluation expectations (Figure 5).

Among other variables, the NBU provides wide explanations on the discount (key) rate according to the legislation, the benchmark for the val- 
Source: Compiled based on the NBU data (2019).

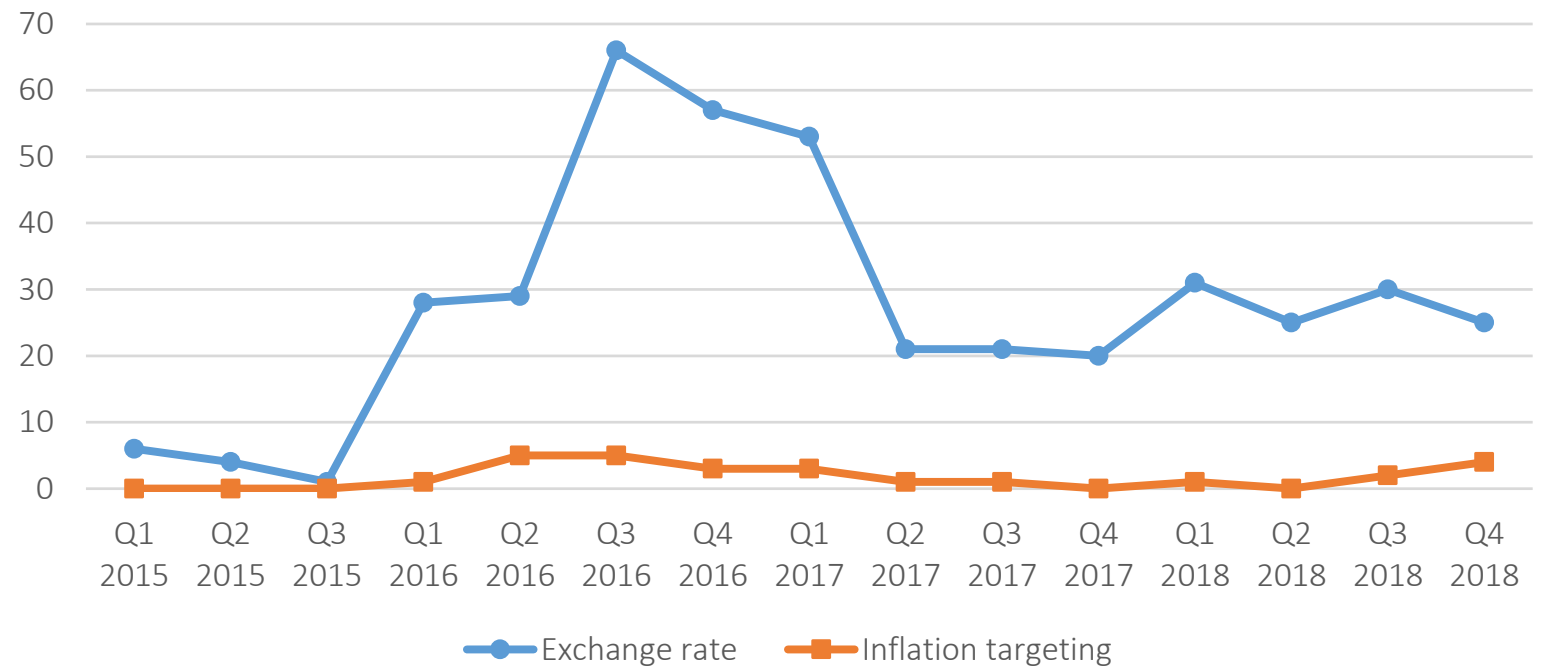

Figure 5. Frequency of expressions in NBU's Inflation Report, 2015-2018, numbers

ue of the borrowed and distributed funds. At the same time, it is tied with and appears to be based on inflationary developments, but there should be practical means to implement inflation targeting. Upon results of analyzing the core (base) consumer inflation and the discount rate dynamics for the period since 2014, during which the central monetary authority became more transparent, the specific trend of the discount rate is pointed out. It follows the core inflation being the level of inflation based on the monetary conditions excluding administrative, seasonal or random influences. The discount rate in Ukraine has been a refinancing cost regulation instrument. The discount rate is supposed to become the factor to achieve price stability as one of the core goals of the NBU with the help of verbal interventions, which will affect population and business expectations, the discount rate is supposed to become the factor to achieve price stability as one of the core goals of the NBU.

Elsewhere in the developed countries, the discount rate equivalent may be the base or key rates (the Fed funds and discount rates for the US) and the main indicator to be mentioned and explained in the authorities' verbal interventions. This is because of the role of the base rates to control inflation and to help reach economic growth by ensuring the response of lenders and borrowers to the base rate change. In the U.S., for example, the two rates perform this role: the
Federal Funds Rate for interbank loans to meet their reserve requirements, and the Federal Reserve Rate charged on funds borrowed by banks from the Fed. The UK has the 'BoE base rate' or 'the interest rate' in the news accrued to banks having deposits with the central bank and used to keep inflation at target. Wide explanation of the key (interest) rate is made by the Norges Bank. Its high representative stated that in the longer term, the interest rate level may influence capital accumulation in the economy. Interest rate expectations for the next few years largely depend on the economic outlook and expectations on monetary policy (Bergo, 2003).

In Ukraine, as the small open economy dependent on external borrowings and on the indirectly related high-level internal dollarization, the exchange rate is of highest interest as the variable, which influences expectations and business decisions. There is such a situation despite the enacted free-floating regime in February 2015, which expanded the scope of indicators to be analyzed by the economic agents as there is no more currency peg. In fact, according to the survey dated December 2017 (Titar, 2018), out of the sample volume of the population representing adult population of Ukraine, about 55.1\% meaningful responses were received on whether respondents knew the current UAH/USD exchange rate. The latter is the highest awareness rate compared to other macroeconomic indicators. 

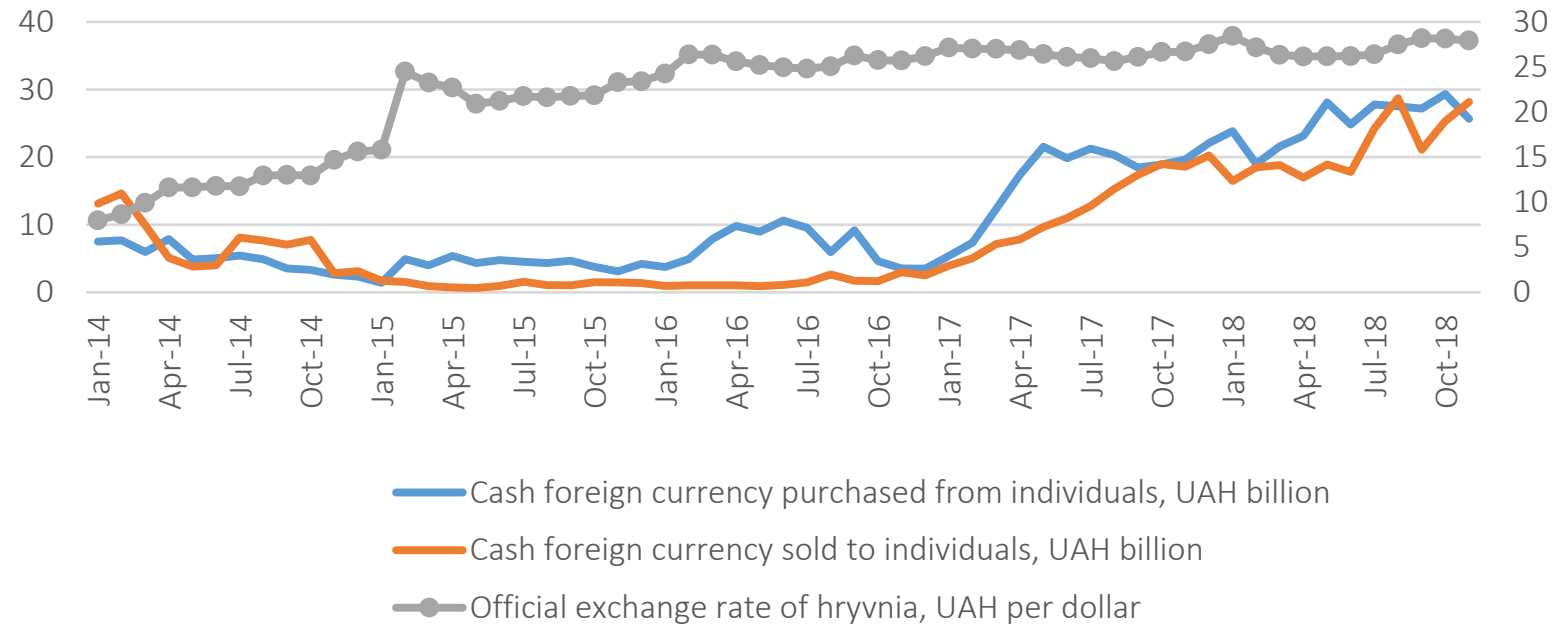

Figure 6. Currency market information, 2014-2018

One of the main indicators of confidence in the banking system in the country is the indicator of the economy dollarization. Ukraine's banking sector remains highly dollarized and surges of purchases of foreign currency by the population demonstrate that (Figure 6). In a crisis period, individuals buy foreign currency at significantly higher volumes than they sell. Nevertheless, against the backdrop of exchange rate stabilization, individuals stop selling the currency in a hurry and begin to sell it gradually.

The devaluation of national currency makes the population more actively transfer their savings into a foreign currency that is affirmed by positive trend rate of foreign currency loans and deposits run-ups (Figure 7). Meanwhile, the dynamics of deposits in the dollar is much more escalating in the banking crisis times, when there is a higher rate of the upturn of dollarization due to a sharp hryvnia devaluation. In addition, the state-guaranteed insufficient amount of indemnity of individual deposits doesn't attract additional funds to the banking system. This indicates a notable level of dollarization and a significant distrust of the population in the banking system.

Business expectations have become largely weighted by the exchange rate because they re-focused on the exchange rate as the main factor of consumer goods' prices versus production expenses' factor, which prevailed earlier. The evidence of distrust in the NBU is a growth of the inconsistency between the official NBU rate and the expected exchange

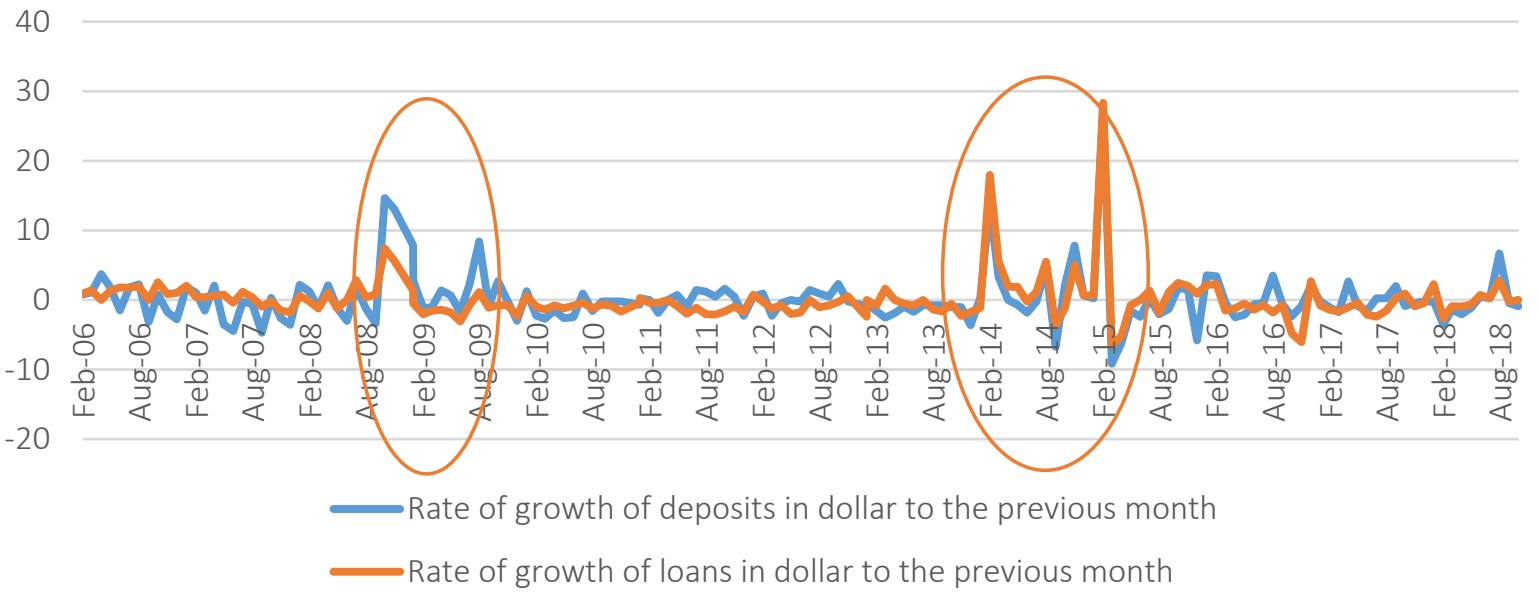

Figure 7. The dollarization level of loans and deposits of residents, $2006-2018$, $\%$ 


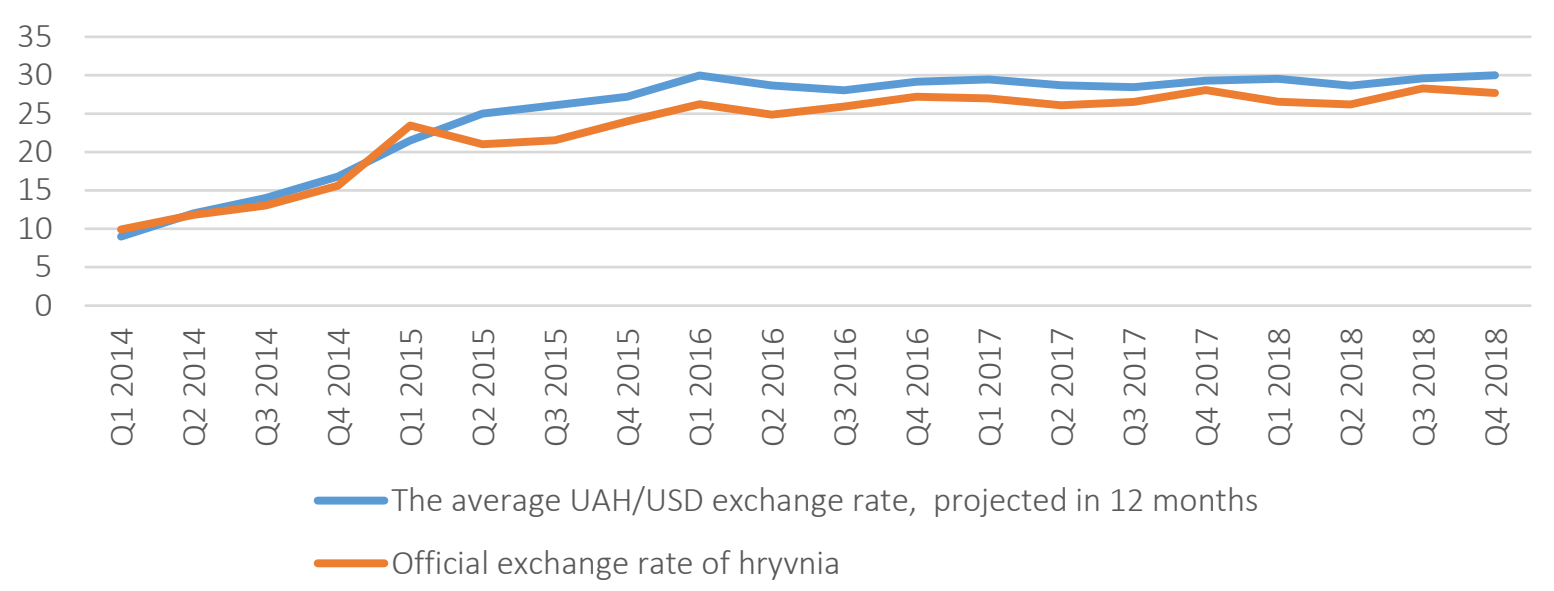

Figure 8. Expectations of business, 2014-2018, UAH per USD

rate of enterprises (Figure 8). The gap indicates the strengthening of devaluation expectations in business.

It can be outlined that now in Ukraine, besides the exchange rate, there are two rates communicated by the central monetary regulator intended to contain signalling information about the cost of the financial resources: the discount rate and inflation target (Figure 9). The 12-month inflation expectations of corporates and the actual reported 12-month inflation (to the same previous year's month) were divergent since the 1st quarter of 2016 (when the inflation targeting policy was introduced by the NBU) until the 3rd quarter of 2018. While the target was $6+/-2 \%$ by end -2018 and the reported 12-month inflation landed to higher $9.8 \%$, the hryvnia lending interest rates were at average 20.5\% in August 2018-March 2019. The discount rate determined to be the signal for the resources' cost and inflation expectations as per the central bank press releases explained by the inflation movements, was increased three times since the 1st quarter of 2017 and left at 18\% in March 2019 since August 2018.

Another approach of indicating trust in the banking system is based on the analysis performed by Bazhal (2019, p. 63), the difference between the M3 and M1 aggregates of the money supply can be taken to estimate "advance" monetary resources and the potential financing of the innovations also increased via multiplier effect, in the forms of M1M3 aggregates including term deposits and secu-

Source: Compiled based on the NBU data (2019).

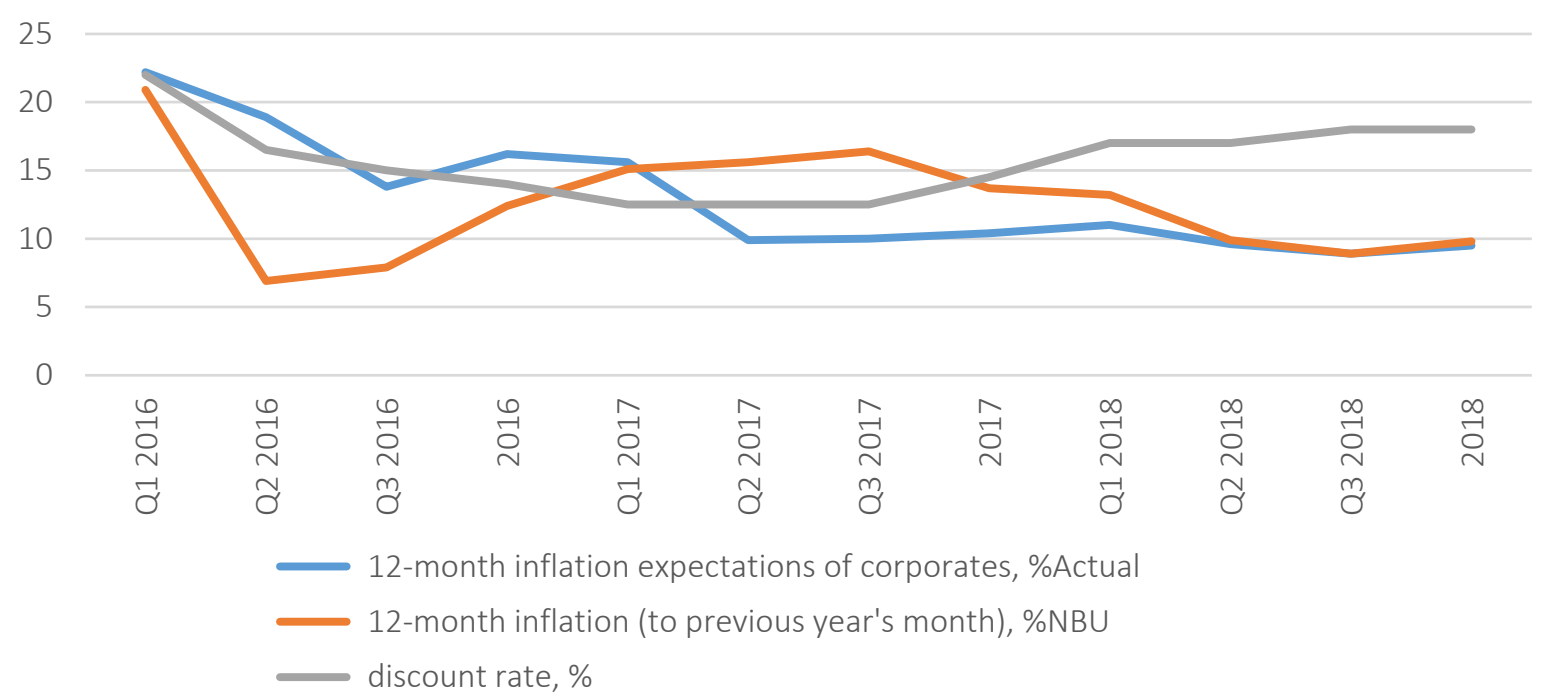

Figure 9. Expected and actual 12-month inflation, 2016-2018, \% 


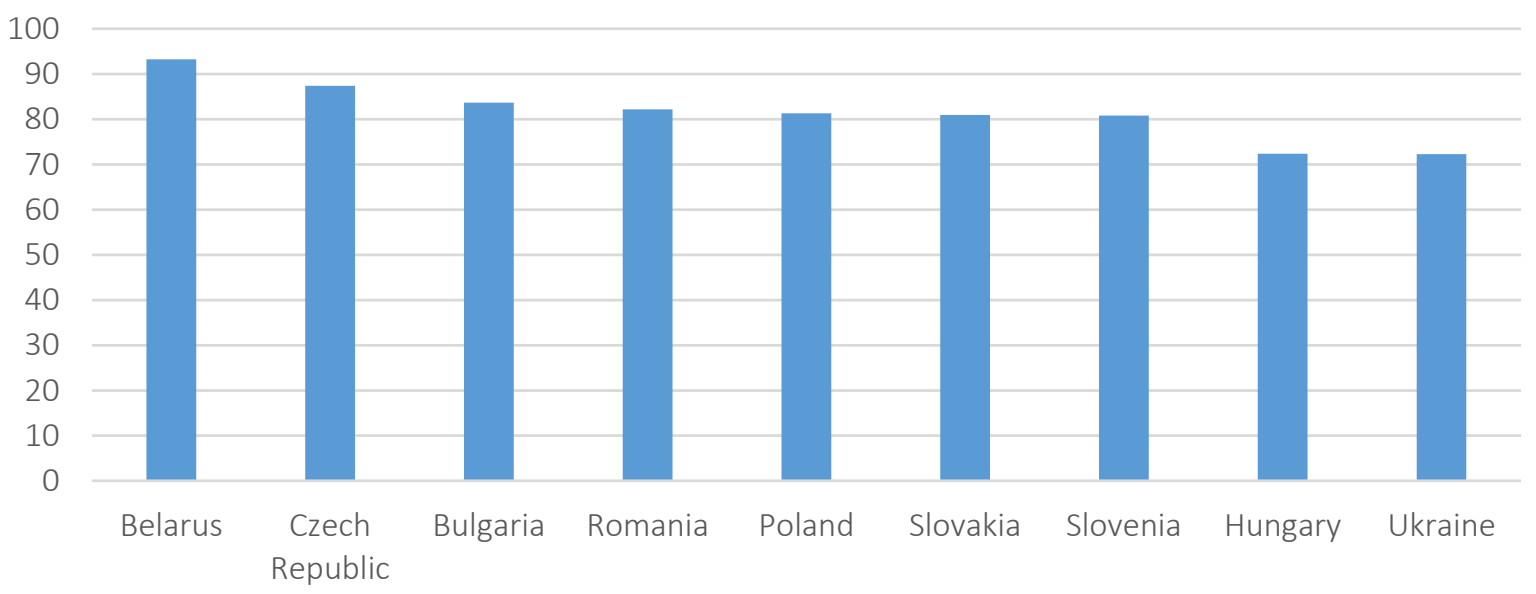

Figure 10. Investment funds' (M3-M0) share in total money supply in Ukraine and peers, as at January $2019, \%$

rities. The difference is regarded as the extent of the monetary funds entrusted to the banking sector. Likewise, comparison of the M3 and M0 aggregates' difference and its weight in total money supply for the selected countries can be applied to estimate trust in the banking system in Ukraine. It states the share of funds absorbed by the banking system in forms other than cash in vault fulfilling the cash transaction function only. Notably, for the three years since the 1st quarter of 2016, quarter by quarter, the share of the resources absorbed by the local banking system has been on the declining trend and has made the share less than in the selected peer countries (Figure 10).

Growing velocity of money circulation in Ukraine is in the inverse correlation to the share of funds involved by the banking system and represented by the M3 and M0 difference. The velocity of money circulation may be factored by the remaining high share of the transaction liquid money (M0 was $27.7 \%$ as at end-January 2019 gradually increasing since early 2016). This witnesses lack of trust in the banking sector. Money circulation grows in crisis times (in particular, the continuing geopolitical crisis) and can mean either the increase in the number of transactions or/and sizable transactions with the shadow economy as well as the high volume of trade on the currency market, including speculations with the currencies.

It should be noted that according to the definition of the Ukrainian monetary regulator, money supply equals M3 embracing M2 and securi- ties (except shares), and as defined by the OECD, embracing repurchase agreements, money market fund units and debt securities (up to two years). M3 is taken as the broad money for the above calculation of the M3 and M0 difference as the share of funds involved in financing economic development in Ukraine. For compatibility purposes, whereas elsewhere in the world (including the Fed), broad money is the M2 aggregate, economy monetization is taken as M2 to GDP according to the World Bank data to compare the monetization level in Ukraine and peers.

By economy monetization level, which is the longer-term resources to be potentially used to finance investment, innovation and economic development, Ukraine has somewhat degraded compared to selected peers. The country basically shows that only the less half of all financial resources are directed towards the development and the second half is mainly the transaction money. This means that money merely fulfils the function of medium of exchange and not fully the store of value. Proceeding from the high dollarization level, unit of account function of money is being fulfilled in Ukraine by the hard currencies rather than by hryvnia. Whereas the money involved by the banking sector includes all M3 components except M0, the money potentially used for investment (M3 less M1) plunged implying that either the long-term resources are barely entrusted to the banking system or economic agents are not eager to save at all or save only in a liquid non-value-adding form. 


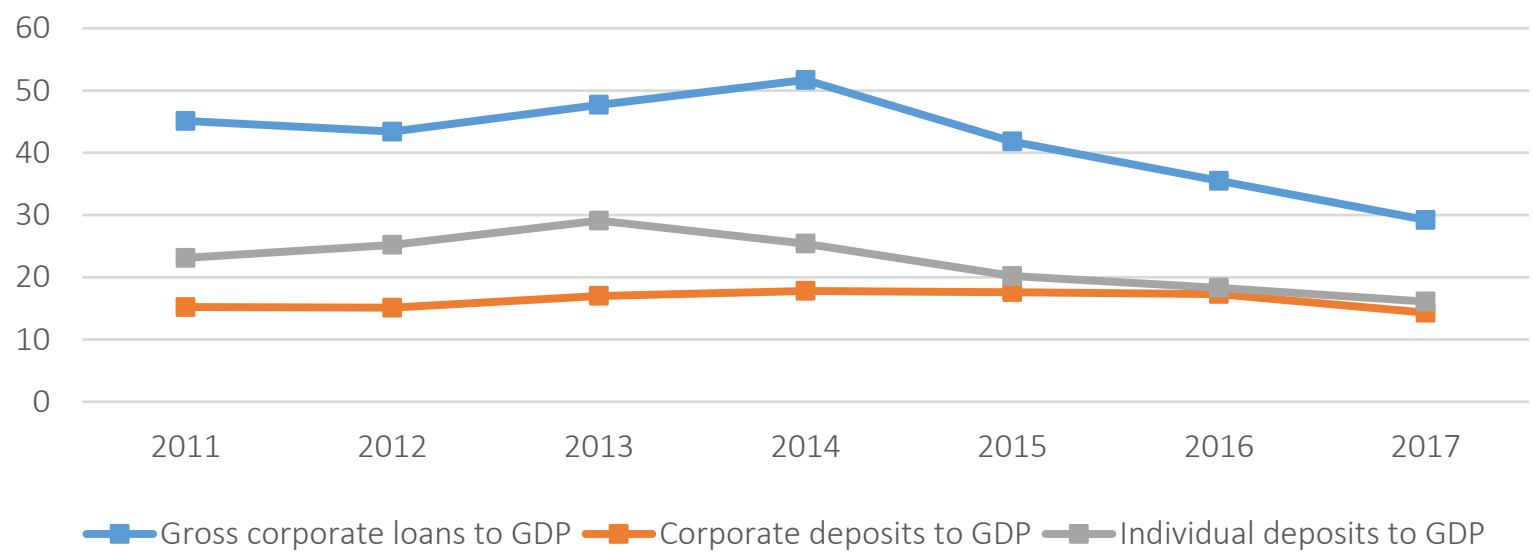

Figure 11. Banking sector penetration indicators of Ukraine, $\%$

Source: Compiled based on the World Bank, FRED (2019) data.

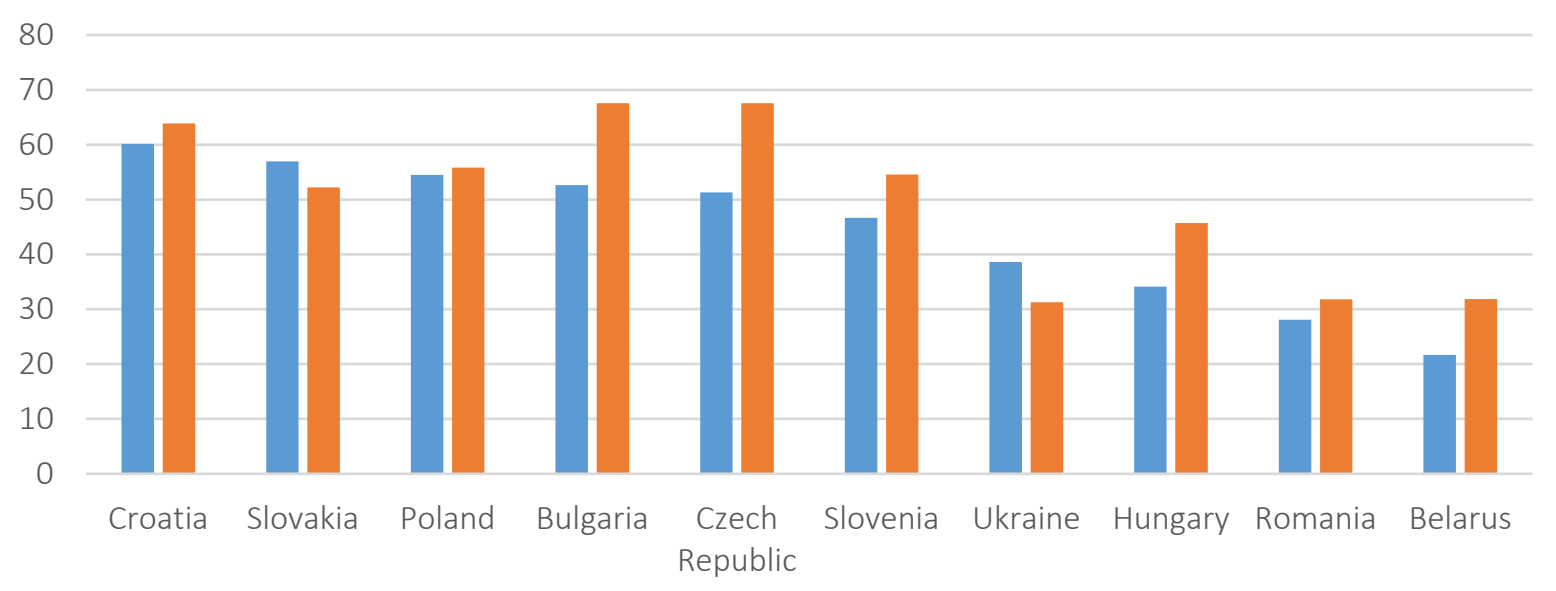

- Domestic credit provided by banking sector to GDP — Bank deposits to GDP

Note: For Czech Republic and Romania, total financial sector deposits to GDP were calculated.

Figure 12. Banking sector penetration indicators, Ukraine and peers, 2016, \%

Next measure suggested as the trust indicator for the banking system is its outreach or penetration, primarily in terms of the volume of deposits the banks are able to attract. In addition, the "feedback" trust of banks to the economic agents expressed in loans provided to economic entities meaning both the share of entities determined eligible for granting a loan and the extent to which banks finance economic development. The Ukrainian monetary regulator witnessed the decline of gross corporate loans to GDP as well as corporate and individual deposits to GDP ratios in 2011 through 2017 (Figure 11).
Among similar countries in terms of economic development, Ukraine takes low positions; this also applies to domestic credit provided by banking sector to GDP and to total deposits (compared to a range of peer countries in 2016, see Figure 12). Further, most of the peers are trending up by said ratios since the beginning of the 2000 -s.

According to Zymovets (2010), the rate of capital accumulation and savings ratio depends on monetary and fiscal policies (implying among other policy measures such as replenishment of the central bank reserves or the absorption of liquidity re- 
sources from the banking sector). Zymovets confirmed that economic development on the term outlook should be provided by productive capital, financed by internal resources. The authors also outlined that since 2005 , owing to the decline of net savings ratio, Ukraine has been dependent on foreign capital to cover the need for productive capital. Therefore, capital needs are financed by the non-long-term and non-stable sources, the fragility of which to put aside external impacts al- so depends on the trustworthy monetary policy (Zymovets, 2010).

As a result of the represented analysis, considering that the banking sector has been one of the primary sources for raising capital investment, it can be stated that increase of trust in the Ukrainian banking system, which coincides with the deeper penetration and outreach of banking services to the economy, is of crucial importance.

\section{CONCLUSION}

The central monetary authority's communication purpose is to resolve the inflation-discount rate expectations dilemma. Inflationary and exchange rate expectations can indirectly impact the formation of the actual prices if we exclude the administratively-regulated prices. Whereas the public, meaning business entities, including those dealing with the external economic activity, and consumers influence respectively supply or demand of the row of products and therefore the prices according to the exchange rate and inflation expectations. The discount rate in its turn has long been not indicative, but the "resulting" or "reaction" rate substantiated by the inflation changes.

Based on the analysis, it can be concluded that inflationary as well as exchange rate expectations (considering the utmost importance of the latter in the Ukrainian social and business entities, especially those involved in export and import operations also influencing local prices) ought to be one of the landmarks for the regulator's monetary policy indicators - the discount rate and inflation target communicated to public via different channels, including press releases, reports, letters and regulations.

Consequently, the trust level can be considered as the "cause", not the "effect" indicator and the qualitative measurement, improved via monetary policies implemented by the trustworthy central bank management and designed to tackle currency speculations and support real economic development. The higher attention to the exchange rate among other monetary indicators shows the lack of trust in the local currency and therefore in the central monetary policy authority, triggering the speculative interest of the economic agents.

Thus, the factors of trust and penetration are to be kept on mind when choosing the communication methods and the way of representing the information. The individual approach to the communication policy as well as to the monetary policy of the central monetary authority in the countries with the small open economy operating their local currencies (other than the hard currencies) should have as the primary goal the increase of trust in the local currency ensuring the explicit fulfilment of the currency function not only as the medium of exchange (also fulfilled during speculation transactions on the currency market), but also as the store of value and unit of account.

\section{REFERENCES}

1. Altavilla, C., Giannone, D., \& Modugno, M. (2014). The Low Frequency Effects of Macroeconomic News on Government Bond Yields (Finance and Economics Discussion Series of Federal Reserve Board, No. 2014-052). Retrieved from https:// www.federalreserve.gov/pubs/ feds/2014/201452/201452pap.pdf

2. Bank of England. (2019). Interest rates and Bank Rate. Retrieved from https://www.bankofengland. co.uk/monetary-policy/theinterest-rate-bank-rate
3. Bazhal, Y. (2019).

Макромонетарна підтримка інноваційного розвитку в умовах сучасної кризи: контекст країн Центральної Європи [Makromonetarna pidtrymka innovatsiinoho 
rozvytku v umovakh suchasnoi kryzy: kontekst krain Tsentralnoi Yevropy]. In Посилення значимості монетарної політики в країнах Центральної і Східної Європи у посткризовий період і рекомендації для України [Posylennia znachymosti monetarnoi polityky $v$ krainakh Tsentralnoi i Skhidnoi Yevropy u postkryzovyi period i rekomendatsii dlia Ukrainy] (pp. 61-71). Kyiv: Zapovit. Retrieved from http:// razumkov.org.ua/uploads/ article/2019_Monetary_Stimuls_ in_CEE_For_Ukraine.pdf

4. Bergo, J. (2003). The role of the interest rate in the economy (Speech Deputy Governor of Norges Bank). Retrieved from https:// www.norges-bank.no/en/Published/Speeches/2003/2003-10-19

5. Bholat, D., Broughton, N., Parker, A., \& Meer, J. T., \& Walczak, E. (2018). Enhancing central bank communications with behavioural insights (Bank of England Staff Working Paper No. 750). Retrieved from https://www. bankofengland.co.uk/-/media/ boe/files/working-paper/2018/ enhancing-central-bank-communications-with-behaviouralinsights.pdf

6. Blinder, A. (2018). Through a Crystal Ball Darkly: The Future of Monetary Policy Communication. AEA Papers and proceedings, 108, 567-571. https://doi.org/10.1257/ pandp. 20181080

7. Blinder, A., Ehrmann, M., Haan, J., \& Jansen, D. J. (2017). Necessity as the mother of invention: monetary policy after the crisis (ECB Working Paper No. 2047). Retrieved from https://www.ecb. europa.eu/pub/pdf/scpwps/ecb. wp2047.en.pdf

8. Christelis, D., Georgarakos, D., Jappelli, T., \& Rooij, M. (2016). Trust in the Central Bank and Inflation Expectations (De Nederlandsche Bank Working Paper No. 537). Retrieved from https:// www.dnb.nl/binaries/Working\%20 paper\%20537_tcm46-350253.pdf

9. Cieslak, A., \& Schrimpf, A. (2018). Non-monetary news in central bank communication (NBER Working Paper No. 25032). Re- trieved from http://www.nber.org/ papers/w25032

10. Coenen, G., Ehrmann, M., Gaballo, G., Hoffmann, P., Nakov, A., Nardelli, S., Persson, E., \& Strasser G. (2017). Communication of monetary policy in unconventional times (ECB Working Paper Series No. 2080). Retrieved from https:// www.ecb.europa.eu/pub/pdf/scpwps/ecb.wp2080.en.pdf

11. Dincer, N., \& Eichengreen, B. (2014). Central bank transparency and independence: updates and new measures. International Journal of Central Banking, 10(1), 189-253. Retrieved from https:// www.ijcb.org/journal/ijcb14q1a6. pdf

12. Draghi, M. (2012). Verbatim of the remarks made by Mario Draghi. Speech at the Global Investment Conference in London. Retrieved from https://www.ecb.europa. eu/press/key/date/2012/html/ sp120726.en.html

13. Draghi, M. (2014). Central bank communication (Opinion piece by President of the ECB). Retrieved from https://www.ecb.europa. eu/press/inter/date/2014/html/ sp140804.en.html

14. Ernst, E., \& Merola, R. (2018). Central bank communication: A quantitative assessment (International Labour Office Working Paper No. 33). Retrieved from https://editorialexpress.com/cgibin/conference/download.cgi?db_ name $=$ ECOMOD2018\&paper_ $\mathrm{id}=89$

15. European Central Bank. (2019). Retrieved from https://www.ecb. europa.eu

16. Federal Reserve Bank of St. Louis. (FRED). (2019, January). Retrieved from https://fred.stlouisfed.org

17. Jahan, S. (2018). Inflation Targeting: Holding the Line. IMF: Finance and development. Retrieved from https://www.imf. org/external/pubs/ft/fandd/basics/ target.htm

18. Janikowski, L., \& Rzonca, A. (2018). Central Bank Communication at Times of Non-Standard Monetary Policies (30 p.) (Mon- etary Dialogue September 2018). Retrieved from http://www. europarl.europa.eu/RegData/ etudes/IDAN/2018/626065/IPOL IDA(2018)626065_EN.pdf

19. Lustenbergera, T., \& Rossib, E. (2017). Does Central Bank Transparency and Communication Affect Financial and Macroeconomic Forecasts? (Swiss National Bank Working Paper No. 12/2017). Retrieved from https://www. snb.ch/n/mmr/reference/working_paper_2017_12/source/working_paper_2017_12.n.pdf

20. Mishchenko, V., Krylova, V., \& Nikonova, M. (2015). Комунікаційна політика центрального банку [Komunikatsiina polityka tsentralnoho banku].Visnyk Natsionalnoho banku Ukrainy, 1, 6-10. Retrieved from http://nbuv. gov.ua/UJRN/Vnbu_2015_1_4

21. National Bank of Ukraine. (2019, January). Retrieved from https:// www.bank.gov.ua

22. Razumkov Center. (2019, January). Retrieved from http://razumkov.org.ua

23. Romanchukevych, V., \& Lymanska, O. (2018). Транспарентність центрального банку та оцінка його комунікацій із питань монетарної політики [Transparentnist tsentralnoho banku ta otsinka yoho komunikatsii iz pytan monetarnoi polityky]. Visnyk Kyivskoho natsionalnoho universytetu imeni Tarasa Shevchenka. Ekonomika, 1(196), 68-76. Retrieved from http://nbuv.gov.ua/ UJRN/VKNU_Ekon_2018_1_12

24. Savchenko, T., \& Zakutniaia, A. (2017). Transparency of the Central Bank as an Inflation Targeting Pillar. Zeszyty Naukowe Wyższej Szkoły Bankowej w Poznaniu, 73(2), 41-52.

25. Shkolnyk, I., \& Savchenko, T. (Ed.) (2018). Транспарентність публічних бінансів - протидія коруnціï [Transparentnist publichnykh finansiv - protydiia koruptsii] (186). Sumy: Yaroslavna. Retrieved from http://essuir.sumdu.edu.ua/bitstream/123456789/72337/1/Publichni_financy_monogr.pdf 
26. State Statistics Service of Ukraine. (2019, January). Retrieved from http://www.ukrstat.gov.ua

27. Svitlychna, V. (2014). Комунікації Національного банку України із зовнішніми користувачами інформації: стан і шляхи вдосконалення [Komunikatsii Natsionalnoho banku Ukrainy iz zovnishnimy korystuvachamy informatsii: stan i shliakhy vdoskonalennia]. Visnyk
Universytetu bankivskoi spravy Natsionalnoho banku Ukrainy, 1(19), 138-143. Retrieved from http://nbuv.gov.ua/UJRN/VUbsNbU_2014_1_28

28. Titar, I. (2018). MacroIgnorance: Which Economic Indicators. VoxUkraine. Retrieved from https:// voxukraine.org/uk/makroneviglastvo-v-yakih-ekonomichnihpokaznikah-oriyentuyutsyaukrayintsi/
29. Trading Economics. (2019, January). Retrieved from https:// tradingeconomics.com

30. World Bank. (2019, January). Retrieved from https://data.worldbank.org

31. Zymovets, V. (2010). Державна фінансова політика економіч ного розвитку [Derzhavna finansova polityka ekonomichnoho rozvytku] (356 p.). Kyiv: NAS of Ukraine, Institute for Economy and Forecasting. 